African Journal of Educational Studies in Mathematics and Sciences Vol. 16, No. 2, 2020

\title{
Teachers' perceptions towards the utilization of WhatsApp in supporting teaching and learning of chemistry during COVID-19 pandemic in Rwandan secondary schools
}

\author{
E. Nsabayezu ${ }^{1}$, A. Iyamuremye ${ }^{2}$, J. D. Kwitonda ${ }^{3}, \&$ A. Mbonyiryivuze ${ }^{4}$
}

\begin{abstract}
This paper reports the results about teachers' perceptions towards the utilization of WhatsApp in supporting teaching and learning of chemistry during the COVID-19 pandemic in Rwandan selected secondary schools. The collected data by using a survey questionnaire were from 18 chemistry teachers in Nyarugenge and Kicukiro Districts. The findings illustrated that WhatsApp is effective for teaching chemistry and supporting students learning. This application promotes students' motivation, engagement, collaboration, interaction, participation, and ubiquitous learning. Despite the facilitation of collaboration between teachers and their students while using WhatsApp, the internet connection related problems including its cost and availability were among the hindering factors for effective collaboration for both students and teachers. The lack of smartphones and computers for some students, teachers, parents, or guardians was among the highlighted limitations for the participation of some students. The limited students' management and their distraction were also highlighted by some teachers. The provision of computers, smartphones, and enough internet connection for all teachers, parents, or guardians were among the proposed potential solutions. To deal with students' management and distractions while learning via WhatsApp, there should be the follow-up and guidance provided by teachers, guardians, or parents. Chemistry teachers and students are recommended to use WhatsApp as a supporting learning tool due to its added value of providing ubiquitous learning. Parents, boards in charge of education, and other educational stakeholders should integrate WhatsApp in teaching and learning to complement classroom learning.
\end{abstract}

Keywords: WhatsApp for teaching and learning, chemistry learning, collaboration, interaction, motivation.

\section{Introduction}

The coronavirus disease 19 (COVID-19) is a highly transmittable and pathogenic viral infection caused by severe acute respiratory syndrome coronavirus 2 (SARS-CoV-2), which emerged in Wuhan, China in December 2019 and spread around the world
(Shereen, et al.,2020). When emerging, this COVID-19 pandemic killed more than eighteen hundred and infected over seventy thousand individuals within the first fifty days of the pandemic (Shereen, et al.,2020). Since the pandemic first emergence, the Rwandan government has established a multidisciplinary team to assess and

1,2,3\&4Ezechiel Nsabayezu, Aloys Iyamuremye, Jean de Dieu Kwitonda, and Agnes Mbonyiryivuze,Academics at the African Centre of Excellence for Innovative Teaching and Learning Mathematics and Science, University of Rwanda - College of Education, Rukara Campus, Kayonza, Rwanda. P.O. BOX: 55 Rwamagana: ${ }^{1}$ Email: ezechielnsabayezu109@gmail.com, Phone: +250787182254; ${ }^{2}$ Email: greatdeist@gmail.com, Phone: +250781157381; ${ }^{3}$ Email: kwitondadieu@gmail.com, Phone: +250785520221, \& ㅌmail: mbonyiryivuzeagnes@yahoo.com, Phone: +250785820176.

Open Access article distributed under the terms of the Creative Commons Attributions License [CC BY-NC-ND 4.0] http://creativecommons.org/licenses/by-nc-nd/4.0. DOI: https://dx.doi.org/10.4314/ajesms.v16i.2.6 
Teachers' perception towards utilization of WhatsApp in supporting teaching and learning of Chemistry during COVID-19 pandemic in Rwandan selected secondary schools

\section{E. Nsabayezu, A. Iyamuremye, J.D. Kwitonda, A. Mbonyiryivuze}

strengthen preparedness and response to it (Exchange-Rwanda, 2020). In Rwanda, the first confirmed case of the COVID-19 pandemic had been declared on 14 March 2020 (MINEDUC, 2020; UN-Rwanda, 2020). The sudden secondary school closures were implemented on 16 March 2020. From the same day, day scholars immediately remained at home and boarding school students were facilitated to return to their respective homes.

The process of returning boarding school students was completed on 18 March 2020 (MINEDUC, 2020). By 21 March 2020, a full lockdown had been implemented and the government temporarily suspended academic activities at secondary schools and universities across the country as a way to curb the spread of the COVID-19 (UNRwanda, 2020; MINEDUC, 2020. To ensure continuity of learning during school closures, the Government of Rwanda in collaboration with its partners including the Rwanda Education Board (REB) engaged several remote learning programs including radio lessons, audio-visual lessons, primarily through television broadcasting and e-learning (World Bank, 2020; MINEDUC, 2020). Therefore, this paper reports the study conducted on 18 teachers in Rwandan selected secondary schools to investigate their perceptions towards utilization of WhatsApp in supporting the teaching and learning of chemistry during the COVID-19 pandemic.

Chemistry is a worthwhile subject that prepares students for the real world of work through career pathways like medicine, agriculture, pharmacy, chemical engineering, food science, environmental studies, and many others. Moreover, it provides answers to the problems faced by our modern society by empowering students to be creative, innovative, and use independent approaches to solve problems (REB, 2015). In Rwandan Education, chemistry plays a considerable role in the country's ambition of developing a knowledge-based society, promoting science and technology competitiveness in the regional and global job market, and addressing the issues of lack of appropriate skills in the Rwandan education system (REB, 2015). As grounded on worldwide and historical sights, all aspects of everyday life like food, drink, clothing, medicine, housing, vehicles, and several others are closely linked to chemistry (Rusmansyah et al., 2019). While learning chemistry, students explore the properties of substances, the processes in which those substances take part, and materials obtained through the modern industry (REB, 2015). Various natural phenomena have existed before people discover chemistry, however, some can be learned after the scientific discovery in research. The complications in sciences and little interest in its studies is the main challenge in teaching and learning chemistry (Treagust, et al., 2018). It was reported that students are not interested in learning chemistry due to the lack of sufficient knowledge about setting up appropriate connections (Illhan, N., et al, 2018). The students start to learn chemistry with enough hope, queries, and interests which disappear after seeing that chemistry is very abstract, mathematical, and theoretical than what they expected (Magwilang, 2016). This is because in some classroom learning teachers emphasize theories than linking the learning concepts with students' daily life (Magwilang, 2016).

Despite its important role, chemistry is one of the science subjects that students often experience inadequate teaching approaches leaving them with a poor understanding of chemistry and a negative attitude towards chemistry (Hassan et al., 2017). Online 
African Journal of Educational Studies in Mathematics and Sciences Vol. 16, No. 2, 2020

learning among others may be a reasonable choice to enable students to improve the learning of Chemistry (Brown et al., 2018). Therefore, during COVID-19 pandemic, online learning including Whatsapp application which serves as a virtual class (Nawaila \& Bicen, 2018) has to be adopted to help students to continue their studies and avoid unnecessary delays and drop out in their studies.

The use of WhatsApp consisting of a crossplatform smartphone application has been adopted for not only socialization but also for teaching and learning processes (Cetinkaya, 2017). This application empowers students to connect with each other and with their instructors by sharing audios, videos, text messages, and documents (La Hanisi et al., 2018). It also provides learners the occasions for online teamwork and collaboration (Barhoumi \& Rossi, 2013) in conjunction with communication and knowledge sharing (Renninger \& Hidi, 2006; Thota \& Divatia, 2015). According to Nuray Zan (2015), WhatsApp in the teaching and learning process is used to increase students' motivation, to strengthen communication, to share information, to help the students to learn, and to plan their studying process (Zan, 2015). WhatsApp application is specially designed for educational undertakings that improve communication, creativity, critical thinking, and problemsolving skills among students (Kufre \& Abe, 2017). WhatsApp is a social network application that gives the opportunity of sending and receiving direct messages and feedback. It is reasonably a novel educational tool which supports teacherstudents relationship by sharing learning activities (Bouhnik \& Deshen, 2014). It has been expressed that WhatsApp enhances the environment for communication among educators and learners by sharing content, activities, and videos (Ujakpa et al., 2018; Conejar et al., 2016; Baccalaureate, 2020; Jones et al., 2010; Stern, 2018). WhatsApp helps to clarify concepts by sharing additional content, audio, and video for great clarification (Cetinkaya, 2017; Kufre \& Abe, 2017). Numerous researches were conducted on the use of WhatsApp application in enhancing the learners' progressive learning. However little has been written on WhatsApp in supporting secondary school students' progressive learning in Chemistry (Zan, 2019). Therefore, this paper reports the study conducted on 18 teachers in Rwandan selected secondary schools to investigate their perceptions towards utilization of WhatsApp in supporting the teaching and learning of chemistry during the COVID-19 pandemic. It aims at examining the effectiveness of WhatsApp in supporting secondary school students' learning of Chemistry; identifying teachers' perception and their understanding toward utilization of WhatsApp to support progressive learning of chemistry and describing the significance and challenges faced by teachers and students when they are using WhatsApp as a learning tool in teaching and learning of chemistry. Moreover, the paper discussed the proposed solutions to the faced challenges. 
Teachers' perception towards utilization of WhatsApp in supporting teaching and learning of Chemistry during COVID-19 pandemic in Rwandan selected secondary schools

E. Nsabayezu, A. Iyamuremye, J.D. Kwitonda, A. Mbonyiryivuze

\section{Methodology}

The reported data in this paper were collected from 18 chemistry teachers in secondary schools in Nyarugenge and Kicukiro Districts selected purposively (Taherdoost, 2018) by using a questionnaire. In terms of gender, the sample comprises of $33.3 \%$ females and $66.7 \%$ of males. From school type point of view, $44.4 \%$ of teachers were from public schools while teachers from private and government-aided schools learning (MINEDUC, 2020). Among the participated teachers, $22 \%$ of them said that they sometimes use WhatsApp groups to collaborate with their students during the COVID-19 pandemic. The other 38.9\% teachers said that they often use WhatsApp groups many times while the remaining $38.9 \%$ confirmed that they always use WhatsApp groups while collaborating with your students during the COVID-19 pandemic. These teachers used this

Table 1 Demographic characteristics of sample: Gender by school and age category

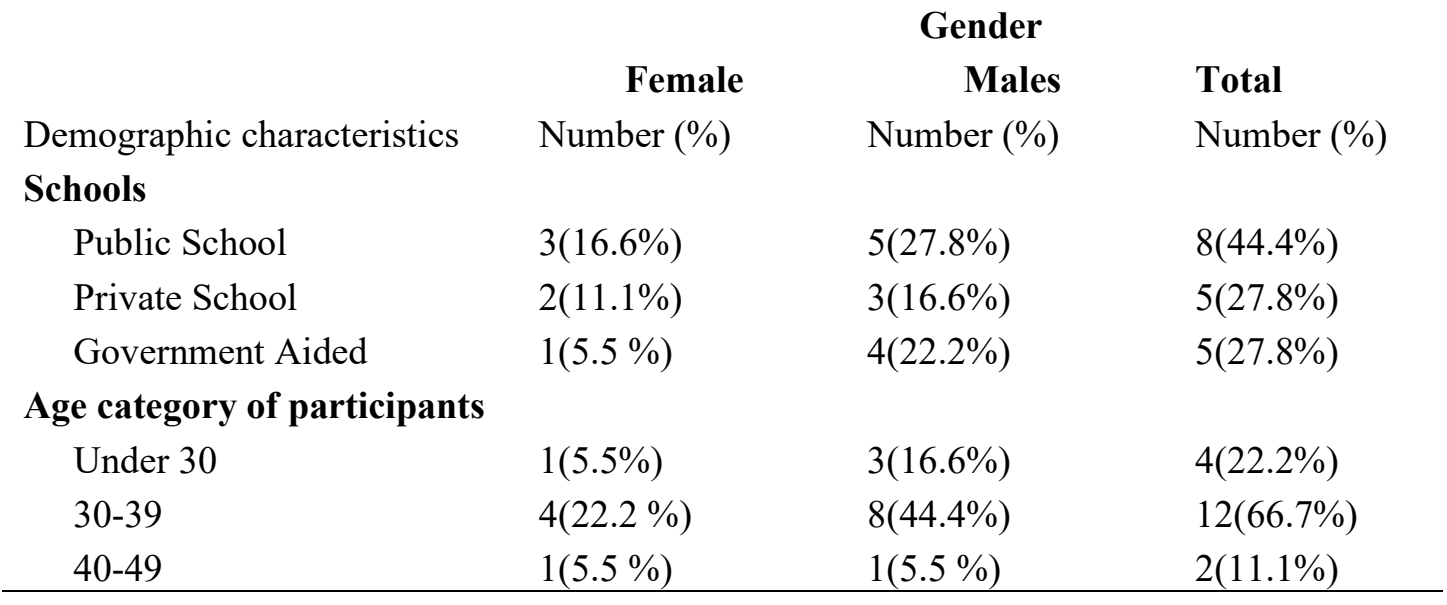

were equally distributed at a rate of $27.8 \%$ of all participants each type of school. For this study, the ethical concerns have been considered. In fact, the identification of the respondents was private and the participation and contribution were voluntarily is shown in Table 1 . The distribution of respondents according to gender, type of school, and age

From Table 1, it is clear that the sample was male-dominated in all participated types of schools. The chosen secondary school chemistry teachers shared the same characteristic of teaching their students during the COVID-19 pandemic by using WhatsApp group. This online teaching was introduced as one of the preventive measures to avoid the spread of the COVID-19 pandemic at the same time to help students application to share the prepared content, audios, videos, and other related learning activities with their students. The same application has been used to share students' answers and queries. Teachers' feedback and students' results on the shared activities were also shared via the WhatsApp group. The used designed questionnaire for data collection contained demographic data, such as school type, sex, and age. This questionnaire also contained 23 closed items consisting of multiple-choice scales investigating teachers' perceptions of the effectiveness of using WhatsApp in teaching and learning of chemistry. Some of the included items were investigating teachers' understanding of its utilization as well as its importance of using WhatsApp during school closure. Additional 6 open-ended 
African Journal of Educational Studies in Mathematics and Sciences Vol. 16, No. 2, 2020

items were used to probe from the participants the benefits of using WhatsApp groups, challenges experienced while teaching and learning by using the WhatsApp group, and some recommended remedies on those challenges. The minimum score for an item is 1 , and its maximum value is 5 . Collected quantitative data from the 18 respondents using questionnaires were analyzed using descriptive statistics carried out using Statistics Package for Social Studies (SPSS) and qualitatively. Descriptive statistical analysis in the form of mean, standard deviation, frequency, and percentage tables was used to show the relative proportion of each level of agreement for each item. The collected qualitative data from open-ended questions were analyzed by using content analysis.

\section{Results and Discussion}

The effectiveness of WhatsApp in supporting secondary school students' learning of chemistry

This section reports responses of the teachers about their perceptions of the effectiveness of WhatsApp in supporting secondary school students' learning of chemistry. The teachers were asked to rate, on a 5-point Likert-scale (i.e., strongly disagree, disagree, neutral, agree, and strongly agree), statements about their perceptions of the use of WhatsApp in the teaching and learning chemistry. Table 2 shows the results of the responses of the teachers about their perceptions of the effectiveness of WhatsApp in supporting Rwandan secondary school students' learning of chemistry.

Table 2 Responses of the teachers about their perceptions of the effectiveness of WhatsApp in supporting secondary school students' learning of Chemistry

\begin{tabular}{|c|c|c|c|c|c|c|}
\hline \multirow{2}{*}{\multicolumn{2}{|c|}{$\begin{array}{l}\text { Statements about teachers' } \\
\text { perceptions of effectiveness of } \\
\text { WhatsApp }\end{array}$}} & \multirow{2}{*}{ Mean } & \multirow{2}{*}{$\begin{array}{l}\text { Std } \\
\text { Div }^{*}\end{array}$} & \multirow{2}{*}{$\begin{array}{l}\text { Agree } \\
\text { N (\%) }\end{array}$} & \multirow{2}{*}{$\begin{array}{l}\text { Neutral } \\
\text { N (\%) }\end{array}$} & \multirow{2}{*}{$\begin{array}{l}\text { Disagree } \\
\mathrm{N}(\%)\end{array}$} \\
\hline & & & & & & \\
\hline a) & $\begin{array}{l}\text { Would you consider WhatsApp } \\
\text { collaboration in chemistry } \\
\text { experience positive? }\end{array}$ & 4.11 & 0.676 & $15(83.4 \%)$ & $3(16.7 \%)$ & $0(0 \%)$ \\
\hline b) & $\begin{array}{l}\text { It was useful to react on the } \\
\text { work of my students through } \\
\text { WhatsApp }\end{array}$ & 4 & 1.372 & $14(77.8 \%)$ & $1(5.5 \%)$ & $3(16.7 \%$ \\
\hline c) & $\begin{array}{l}\text { Student's follow instruction as it } \\
\text { was stated while learning via } \\
\text { WhatsApp }\end{array}$ & 4.56 & 0.784 & $15(83.3 \%)$ & $3(16.7 \%)$ & $0(0 \%)$ \\
\hline d) & $\begin{array}{l}\text { Students react on teacher's task } \\
\text { timely }\end{array}$ & 3.72 & 1.074 & $11(61.1 \%)$ & $4(22.2 \%)$ & $3(16.7 \%)$ \\
\hline e) & $\begin{array}{l}\text { The interaction between } \\
\text { student-student and student- } \\
\text { teacher were increased through } \\
\text { WhatsApp collaboration }\end{array}$ & 3.89 & 1.132 & $16(88.9 \%)$ & 0 & $2(11.1 \%)$ \\
\hline
\end{tabular}


Teachers' perception towards utilization of WhatsApp in supporting teaching and learning of Chemistry during COVID-19 pandemic in Rwandan selected secondary schools

\section{E. Nsabayezu, A. Iyamuremye, J.D. Kwitonda, A. Mbonyiryivuze}

Table 2 shows findings about teachers' perceptions on the effectiveness of WhatsApp in supporting secondary school students' learning of chemistry. While probing teachers' perception, they have shown high agreement of $83.4 \%, 77.8 \%$, $83.3 \%, 61.1 \%$, and $88.9 \%$ respectively for the five questions. Only a few teachers have shown a level of disagreement on the usefulness of reacting to their students' work through WhatsApp and the time that students take to react to teachers' tasks. The rate of disagreement on these two items was $16.7 \%$. To support the collected quantitative data, teachers were asked what they liked about collaborating with their students via WhatsApp and explain the reasons. Despite the effort, commitment, the time needed from students, teachers, and parents or guardians while teaching and learning chemistry via WhatsApp, this approach was claimed to facilitate students' learning during the COVID-19 Pandemic. 27.7\% of the respondents said that this teaching approach increased students' motivation. Besides, some teachers liked the way students reacted and expressed their ideas, $44.4 \%$ of respondents mentioned that this approach improved interaction among students and teachers. Some teachers also said that almost all students liked to use computers and smartphones specifically while sharing audio/video files to their teachers and vice versa. The approach was also claimed to improve engagement and collaboration among students and teachers.

The obtained results from this study are in good agreement with the results of the study conducted on using WhatsApp in teaching chemistry and biology to tenth graders in Arab American University, Palestine (Abualrob, 2020). In his study, Abualrob (2020) found that WhatsApp increased students' interaction and encouragement greater than before its integration in their education system. The findings of this study are also in agreement with the study conducted by Cetinkaya in 2017 which revealed that WhatsApp is an effective supporting technology tool in enhancing teaching and learning (Cetinkaya, 2017). These results are in agreement with the findings of the research on students' experiences of mobile learning opined that WhatsApp is very effective to encourage learners' interaction and retention in a time of learning (Bansal \& Joshi, 2014). WhatsApp is an essential collaborative tool which has also to be used for instruction purpose in the current 21st-century education as it makes learning very interesting (Kufre \& Abe, 2017).

Teacher's perception and understanding toward utilization of WhatsApp to support progressive learning of chemistry

The next section reports responses of the teachers about their perceptions and their understanding toward utilization of WhatsApp to support progressive learning of chemistry. The teachers were also asked to rate, on a 5-point Likert-scale (i.e., strongly disagree, disagree, neutral, agree, and strongly agree), statements about their perceptions and understanding toward utilization of WhatsApp in the teaching and learning chemistry. Table 3 shows the results of the responses of the teachers. 
African Journal of Educational Studies in Mathematics and Sciences Vol. 16, No. 2, 2020

Table 3 Responses of the teachers' perceptions and understanding toward utilization of WhatsApp to support progressive learning of chemistry

\begin{tabular}{|c|c|c|c|c|c|c|}
\hline \multirow{2}{*}{\multicolumn{2}{|c|}{$\begin{array}{l}\text { Statements about teachers' } \\
\text { perceptions and understanding } \\
\text { toward utilization of WhatsApp }\end{array}$}} & \multirow[b]{2}{*}{ Mean } & \multirow{2}{*}{$\begin{array}{l}\text { Std } \\
\text { Div }^{*}\end{array}$} & \multirow{2}{*}{$\begin{array}{l}\text { Agree } \\
\text { N (\%) }\end{array}$} & \multirow{2}{*}{$\begin{array}{l}\text { Neutral } \\
\text { N (\%) }\end{array}$} & \multirow{2}{*}{$\begin{array}{l}\text { Disagree } \\
\mathrm{N}(\%)\end{array}$} \\
\hline & & & & & & \\
\hline a) & $\begin{array}{l}\text { It was easy to collaborate with } \\
\text { students via WhatsApp groups }\end{array}$ & 4.17 & 0.985 & $15(83.3 \%)$ & $1(5.6 \%)$ & $2(11.1 \%)$ \\
\hline b) & $\begin{array}{l}\text { I like to collaborate with my } \\
\text { students via WhatsApp groups }\end{array}$ & 4.5 & 0.514 & $18(100 \%)$ & $0(0 \%)$ & $0(0 \%)$ \\
\hline c) & $\begin{array}{l}\text { WhatsApp is easy to use for } \\
\text { both teachers and learners }\end{array}$ & 4.22 & 0.878 & $15(83.3 \%)$ & $2(11.1 \%)$ & $1(5.6 \%)$ \\
\hline d) & $\begin{array}{l}\text { It was difficult to collaborate } \\
\text { with my student via WhatsApp }\end{array}$ & 2.33 & 1.283 & $3(16.7 \%)$ & $6(33.3 \%)$ & $9(50 \%)$ \\
\hline e) & $\begin{array}{l}\text { Effective collaboration with my } \\
\text { students via WhatsApp was } \\
\text { hindered by low internet } \\
\text { connection }\end{array}$ & 3.44 & 1.338 & $9(50 \%)$ & $5(27.8 \%)$ & $4(22.2 \%)$ \\
\hline f) & $\begin{array}{l}\text { Utilization of WhatsApp is } \\
\text { expensive }\end{array}$ & 3.56 & 1.504 & $12(66.6 \%)$ & $1(5.6 \%)$ & $5(27.8 \%)$ \\
\hline g) & $\begin{array}{l}\text { I felt comfortable while } \\
\text { discussing with my students via } \\
\text { WhatsApp }\end{array}$ & 3.83 & 1.295 & $14(77.7 \%)$ & $1(5.6 \%)$ & $3(16.7 \%)$ \\
\hline h) & $\begin{array}{l}\text { I can recommend administrators } \\
\text { and other schools to use } \\
\text { WhatsApp while collaborating }\end{array}$ & 4.28 & 1.127 & $14(77.7 \%)$ & $3(16.7 \%)$ & $1(5.6 \%)$ \\
\hline
\end{tabular}

Table 3 shows the findings about teachers' perceptions towards the utilization of WhatsApp. The study results revealed that all participants liked to collaborate with their students via WhatsApp groups. 83.3\% of them accepted that WhatsApp is easy to use for both teachers and learners. The same number of participants said that the collaboration with their students is easy while using this application. This was confirmed by a high level of disagreement of $50 \%$ on the item saying that it was difficult to collaborate with their students via WhatsApp. Despite the facilitation of collaboration between teachers and their students while using WhatsApp, a considerable number of participants said that low internet connection was one among hinder factors for effective collaboration and that the utilization of WhatsApp is expensive. A considerable number at a rate of $77.7 \%$ accepted that they were comfortable while discussing with the student via WhatsApp and they recommended administrators and other schools to use WhatsApp while collaborating. Participants mentioned some advantages of using WhatsApp while collaborating with their students that include supporting the sharing of content through video and audio or records. Moreover, it facilitates the students' learning and improved their collaboration. Concerning teachers' feelings to express their ideas to 
Teachers' perception towards utilization of WhatsApp in supporting teaching and learning of Chemistry during COVID-19 pandemic in Rwandan selected secondary schools

E. Nsabayezu, A. Iyamuremye, J.D. Kwitonda, A. Mbonyiryivuze

the students while using WhatsApp group, $66.6 \%$ of all participants said that they were feeling comfortable to express their ideas. Only $16 \%$ of participants said the opposite. When asked if being a member of the WhatsApp groups improved their class
2020). Moreover, Agustrianita (2017) found that teachers have positive perceptions about the implementation of social media as a helpful learning tool to develop their professional and create meaningful teaching and learning environment.

Table 4 Responses of the teachers' perceptions about the importance of using WhatsApp in teaching and learning of chemistry

\begin{tabular}{|c|c|c|c|c|c|c|}
\hline \multirow[t]{2}{*}{ a) } & \multirow{2}{*}{$\begin{array}{l}\text { Statements about teachers' } \\
\text { perceptions about the importance } \\
\text { of using WhatsApp }\end{array}$} & \multirow[b]{2}{*}{ Mean } & \multirow{2}{*}{$\begin{array}{l}\text { Std } \\
\text { Div }^{*}\end{array}$} & \multirow{2}{*}{$\begin{array}{l}\text { Agree } \\
\text { N (\%) }\end{array}$} & \multirow{2}{*}{$\begin{array}{l}\text { Neutral } \\
\mathrm{N}(\%)\end{array}$} & \multirow{2}{*}{$\begin{array}{l}\text { Disagree } \\
\mathrm{N}(\%)\end{array}$} \\
\hline & & & & & & \\
\hline b) & $\begin{array}{l}\text { WhatsApp helps me to give } \\
\text { students more clarification on } \\
\text { chemistry concepts }\end{array}$ & 4.17 & 0.707 & $15(83.3 \%)$ & $3(16.7 \%)$ & $0(0 \%)$ \\
\hline c) & $\begin{array}{l}\text { WhatsApp helps me to share } \\
\text { learning resources with my students }\end{array}$ & 4.56 & 0.616 & $17(94.4 \%)$ & $1(5.6 \%)$ & $0(0 \%)$ \\
\hline d) & $\begin{array}{l}\text { The instructions from the teacher } \\
\text { helped identify areas of agreement } \\
\text { and disagreement of students on } \\
\text { course topics that helped them to } \\
\text { learn. }\end{array}$ & 3.94 & 0.802 & $12(66.7 \%)$ & $6(33.3 \%)$ & $0(0 \%)$ \\
\hline e) & $\begin{array}{l}\text { Teacher encouraged learners to } \\
\text { explore new concepts through } \\
\text { WhatsApp groups }\end{array}$ & 4.39 & 0.608 & $17(94.4 \%)$ & $1(5.6 \%)$ & $0(0 \%)$ \\
\hline f) & $\begin{array}{l}\text { WhatsApp communication is an } \\
\text { excellent medium for social } \\
\text { interaction in teaching and learning } \\
\text { chemistry }\end{array}$ & 3.72 & 0.826 & $11(61.1 \%)$ & $6(33.3 \%)$ & $1(5.6 \%)$ \\
\hline g) & $\begin{array}{l}\text { Students were engaged more in } \\
\text { WhatsApp collaboration than in } \\
\text { classroom discussion }\end{array}$ & 2.78 & 1.353 & $7(38.9 \%)$ & $4(22.2 \%)$ & $7(38.9 \%)$ \\
\hline
\end{tabular}

interaction, most of them participated teachers said that class interaction was improved at a rate of $88.8 \%$. Only $11.1 \%$ said that there was no improvement in class interaction. This study found that most of the participated teachers have shown positive perceptions towards teaching and learning chemistry by using WhatsApp. The found results were in agreement with those found in the literature indicating that WhatsApp increased personal interaction and interpersonal development (Motteram et al.,
Results on the importance of using WhatsApp in teaching and learning of chemistry

The final section of the results examined responses of the teachers about their perceptions about the importance of using WhatsApp in teaching and learning of chemistry. The teachers were once more asked to rate, on a 5-point Likert-scale (i.e., strongly disagree, disagree, neutral, agree, and strongly agree), statements about their 
African Journal of Educational Studies in Mathematics and Sciences Vol. 16, No. 2, 2020

perceptions about the importance of using WhatsApp in teaching and learning of chemistry. The results of the responses are summarised in Table 4.

The results in Table 4 revealed that there was a high level of agreement of $83.3 \%, 94.4 \%$, $66.7 \%, 94.4 \%, 61.1 \%$, and $38.8 \%$ for the first six questions respectively and $72.3 \%$ for the last question. For this study, there was a high level of neutral of $50 \%$ for the question asking whether via WhatsApp collaboration, brainstorming, and searching relevant information were increased. Few participants showed a level of disagreement at a rate of $38.9 \%$ on the question asking whether the students' engagement was more in WhatsApp collaboration than in classroom discussion. In this study, teachers were asked their views on whether the WhatsApp application is more advantageous for teachers than other communication mediums done inside the classroom and to provide their reasons. This study revealed that WhatsApp cannot replace the ways of teaching in the classroom as indicated by $83.3 \%$ of all participants. WhatsApp can be used to support other teaching approaches whenever possible. Regarding the improvement of students' attitudes towards chemistry, while teachers are members of WhatsApp groups, it was shown that $83.3 \%$ said that there was an improvement in their students' attitudes towards chemistry. Some of the provided reasons were that students' motivation, engagement, interaction, and participation were increased. However, some teachers said that some students were not fully committed during the discussion. These findings are in line with the results of a study that revealed that WhatsApp supports collaboration and sharing of learning contents, activities, and provides a conducive learning environment (Bouhnik $\&$ Deshen, 2014).
These results are in agreement with the literature which indicated that WhatsApp is significant for education purposes as it provides the accessibility of learning materials and allows the learning at anytime and anywhere in a safe way. WhatsApp inspires cooperation and strengthens motivation to be active in doing the learning tasks (Rambe \& Chipunza, 2013). WhatsApp enhances learners' motivation for the course, reinforce communication, boosting information sharing between learners, and improve learning (Zan, 2019). When WhatsApp is used in teaching and learning, it improves learner-learner interaction and learners-instructor and improves knowledge construction (Amry, 2014; Kufre \& Abe, 2017). The required knowledge and information are constructed via the use of WhatsApp in teaching and learning (Barhoumi, 2015). These findings are also in line with the literature stressed that WhatsApp chat is the most desired application which promotes collaborative learning and encourages participation in learning even for learners with disabilities (Bansal \& Joshi, 2014; Calvo et al., 2014). Amry (2014) stressed that online learning facilitates to construct experience and knowledge by sharing questions, examining the content, sharing views, displaying agreement, and disagreement in the direction of another topic. The study results are in line with the findings of the study showed that WhatsApp seemed like a platform for selfengaged learning, meaningful engagement in learning, and construction of significance knowledge (Annamalai, 2018). It was identified that WhatsApp has a vital exceptional role in promoting a noble learner-instructor relationship and a good virtual learning environment (Hershkovitz et al., 2019). 
Teachers' perception towards utilization of WhatsApp in supporting teaching and learning of Chemistry during COVID-19 pandemic in Rwandan selected secondary schools

E. Nsabayezu, A. Iyamuremye, J.D. Kwitonda, A. Mbonyiryivuze

The challenges faced by teachers and some proposed potential solutions to those challenges

Despite the facilitation of collaboration between teachers and their students while using WhatsApp, some face the challenges were reported by some participated chemistry teachers. It was found that the participation of all students was limited by the lack of internet connectivity or smartphones to be used. $94.4 \%$ of the participants mentioned challenges related to internet connection and phones. Other highlighted challenges included the lack of internet connectivity and low internet connectivity. The found results are in agreement with those found by Mbukusa in 2018. This author also showed that students enjoy the use of WhatsApp in learning but the internet connection became a barrier that led to a slow communication. Moreover, the challenges related to the low phone capacity were mentioned by $33.3 \%$ of participants. The participated teachers at a rate of $33.3 \%$ argued that the management of their students was limited. Some of them said that when using WhatsApp, students can be distracted and use it for other purposes that are not related to their studying. Moreover, some participants said that while using WhatsApp, teachers are not sure if the provided work is done by their students only. To handle the faced challenges, it was proposed that in addition to the guidance and follow-up provided by students' guardians or parents to focus on their lesson, the provision of computers, good smartphones, and enough internet connection for teachers, parents, or guardians should be taken into consideration. Moreover, collaboration among parents, government, and different stakeholders is needed.

\section{Conclusion and Recommendations}

This study showed that WhatsApp supports students' learning of chemistry during the COVID-19 pandemic as indicated by most of the respondents. This application was found to be useful in helping students to construct their knowledge and inspire learners to participate in their learning. By using WhatsApp, it was found that collaboration between teachers and students increases. The participants argued that even if WhatsApp is more advantageous for supporting the learning of chemistry, it cannot replace the normal classroom teaching and learning. The highlighted challenges included the problems related to internet connectivity and smartphones. Based on the findings of the current study, the authors recommend that WhatsApp should not only be used for communication but also in supporting the process of teaching and learning. Secondary chemistry teachers and learners should be encouraged to use WhatsApp to advance visualization aptitudes of chemistry learning concepts. They are also recommended to supplement their classroom teaching by using novel technologies like WhatsApp group conversation. WhatsApp should be understood as a technology learning tool that has to be integrated into education. The parents are advised to guide and monitor students learning when they are using WhatsApp so that they can remain focused on their learning. Moreover, educational stakeholders should integrate WhatsApp in teaching and learning to supplements classroom learning.

\section{References}

Abualrob, M. (2020). Using WhatsApp in teaching chemistry and biology to tenth graders. Contemporary Educational Technology, 11(1), 79100. 
African Journal of Educational Studies in Mathematics and Sciences Vol. 16, No. 2, 2020

Agustrianita, A. (2017). Teachers' perceptions towards social media use to improve professional development and integration in English language teaching. English Language and Literature International Conference (ellic) Proceedings, 17-22.

Amry, A. B. (2014). The impact of WhatsApp mobile social learning on the achievement and attitudes of female students compared with face to face learning in the classroom. European Scientific Journal, 10(22), 116-136.

Annamalai, N. (2018). Whatsapp is the message: out-of-class communication, student-teacher relationship, and classroom environment. Malaysian Journal of Learning and Instruction, 15(2), 207-225.

Bansal, T., \& Joshi, D. (2014). A study of students' experiences of mobile learning. Global journal of HumanSocial Science. 14(4).

Barhoumi, C. (2015). The effectiveness of WhatsApp mobile learning activities guided by activity theory on students' knowledge management. Contemporary Educational Technology, 6(3), 221-238. https://doi.org/10.30935/cedtech/61 51

Barhoumi, C., \& Rossi, P. G. (2013). The effectiveness of instruction-oriented hypertext systems compared to direct instruction in e-learning environments. Contemporary Educational Technology, 4(4), 281308. https://doi.org/10.30935/cedtech/61 09
Bouhnik, D., \& Deshen, M. (2014). Whatsapp goes to school: Mobile instant messaging between teachers and students. Journal of Information Technology Education: Research, 13, 217-231. https://doi.org/10.28945/2051

Brown, K. K., Gilmore, M. W., Dillihunt, M., \& Minor, K. (2018). Utilizing online technology to effectively teach chemistry in secondary education. Modern chemistry \& applications, 6(1), 14-16. https://doi.org/10.4172/23296798.1000244

Calvo, R., Arbiol, A., \& Iglesias, A. (2014). Are all chats suitable for learning purposes? a study of the required characteristics. 5th International Conference on Software Development and Technologies for Enhancing Accessibility and Fighting Info-exclusion, 27(dsai 2013), 251-260. https://doi.org/10.1016/j.procs.2014. 02.028

Cetinkaya, L. (2017). The impact of WhatsApp use on success in the education process. International Review of Research in Open and Distance Learning, 18(7), 59-74. https://doi.org/10.19173/irrodl.v18i7 .3279

Conejar, R. J., Jung, R., \& Kim, H. K. (2016). Smart home IP-based uhealthcare monitoring system using mobile technologies. International Journal of Smart Home, 10(10), 283-292. https://doi.org/10.14257/ijsh.2016.1 $\underline{0.10 .26}$

Hassan, A. A., Ali, H. I., Salum, A. A., Kassim, A. M., Elmoge, Y. N., \& 
Teachers' perception towards utilization of WhatsApp in supporting teaching and learning of Chemistry during COVID-19 pandemic in Rwandan selected secondary schools

E. Nsabayezu, A. Iyamuremye, J.D. Kwitonda, A. Mbonyiryivuze

Amour, A. A. (2017). Factors affecting students, performance in chemistry: case study in zanzibar secondary schools. International journal of social, behavioral, educational, economic, business and industrial engineering vol:9, 9 (november 2015), 1-9.

Hershkovitz, A., Elhija, M. A., \& Zedan, D. (2019). WhatsApp is the message: out-of-class communication, student-teacher relationship. Journal of Information Technology Education: Research, 18, 63-95. https://doi.org/10.28945/4183

İlhan, N., Yildirin, Ali., Yilmaz, S. (2016). The effect of context-based chemical equilibrium on grade 11 students' learning, motivation and constructivist learning environment. International Journal of Environmental \& Science Education, 372(2), 2499-2508. https://doi.org/10.1056/nejmoa1407 279

International Baccalaureate. (2020). Online learning, teaching, and education continuity planning for schools. International Baccalaureate, 1-13. Retrieved from ibo.org

Jones, N., Blackey, H., Fitzgibbon, K., \& Chew, E. (2010). Get out of myspace! Computers and Education, 54(3), 776-782. https://doi.org/10.1016/j.compedu.2 009.07.008

Kufre, P., \& Abe, E. (2017). Effectiveness of WhatsApp as a collaborative tool for learning among undergraduate students in the University of Uyo, Akwa Ibom State. International Journal of Advanced Education and Research, 2(5), 43-46.
La Hanisi, A., Risdiany, R., Dwi Utami, Y., $\&$ Sulisworo, D. (2018). The use of WhatsApp in collaborative learning to improve English teaching and learning process. International Journal of Research Studies in Educational Technology, 7(1). https://doi.org/10.5861/ijrset.2018.3 004

Magwilang, E. (2016). Teaching Chemistry in Context: Its Effects on Students' Motivation, Attitudes, and Achievement in Chemistry. International Journal of Learning, Teaching and Educational Research, 15(4).

Mbukusa, N. R. (2018). Perceptions of students' on the use of WhatsApp in teaching methods of English as second language at the University of Namibia. Journal of Curriculum and Teaching, $\quad 7(2), \quad 112$. https://doi.org/10.5430/jct.v7n2p112

MINEDUC. (2020). Keeping the doors open for learning: Response plan of Ministry of Education. Kigali: MINEDUC.

Motteram, G., Dawson, S., \& Al-Masri, N. (2020). WhatsApp supported language teacher development: a case study in the Zaatari refugee camp. Education and Information Technologies. https://doi.org/10.1007/s10639-02010233-0

Nawaila, M. B., \& Bicen, H. (2018). Whatsapp as a tool for distance learning. Ponte international scientific researchs journal, 74(1). https://doi.org/10.21506/j.ponte.201 8.1 .36

Rambe, P., \& Chipunza, C. (2013). Using mobile devices to leverage student 
African Journal of Educational Studies in Mathematics and Sciences Vol. 16, No. 2, 2020

access to collaboratively-generated resources: a case of WhatsApp instant messaging at a South African university. International Conference on Advanced Information and Communication Technology for Education., (icaicte). https://doi.org/10.2991/icaicte.2013. 66

Renninger, S., \& Hidi, K. A. (2006). The four-phase model of interest development. Educational Psychologist, 41(2), 111-127,. https://doi.org/10.1207/s15326985e p4102

Rusmansyah, Yuanita, L., Ibrahim, M., Isnawati, \& Prahani, B. K. (2019). Innovative chemistry learning model: Improving the critical thinking skill and self-efficacy of pre-service chemistry teachers. Journal of Technology and Science Education, 9(1), 59-76. https://doi.org/10.3926/jotse.555

Shereen, M. A., Khan, S., Kazmi, A., Bashir, N., \& Siddique, R. (2020). COVID19 infection: Origin, transmission, and characteristics of human coronaviruses. Journal of Advanced Research(24), 91-98.

Stern, J. (2018). Introduction to online teaching and learning. International Journal of Science Education, (3), 110. https://doi.org/10.1002/9781118784 235.eeltv06b

Taherdoost, H. (2018). Sampling methods in research methodology; how to choose a sampling technique for research. International Journal of Academic Research in Management, 5(2), 19-27. https://doi.org/10.2139/ssrn.320503
5

The World Bank. (2020). How countries are using edtech (including online learning, radio, television, texting) to support access to remote learning during the COVID-19 pandemic. 19, 1-36. Retrieved from https://www.worldbank.org/en/topic /edutech/brief/how-countries-areusing-edtech-to-support-remotelearning-during-the-covid-19pandemic

Thota, R. S., \& Divatia, J. V. (2015). WhatsApp: what an app! Indian Journal of Critical Care Medicine, 19(6), 363-365. https://doi.org/10.4103/09725229.158288

Treagust, D., Nieswandt, M., \& Duit, R. (2018). Sources of students difficulties in learning Chemistry. Educación Química, 11(2), 228. https://doi.org/10.22201/fq.1870840 4e.2000.2.66458

Ujakpa, M. M., Heukelman, D., Lazarus, V. K., Neiss, P., \& Rukanda, G. D. (2018). Using WhatsApp to support communication in teaching and learning. Ist-Africa Week Conference, ist-Africa 2018.

UN-Rwanda. (2020). The socio-economic impact of COVID-19 in Rwanda. Kigali: UN-Rwanda

Zan, N. (2015). The effects of smartphone use on organic chemical compound learning. US-China Education Review A, 5(2), 105-113. https://doi.org/10.17265/2161$623 \mathrm{x} / 2015.02 .003$

Zan, N. (2019). Communication channel between teachers and students in chemistry education: WhatsApp. US-China Education Review A, 9(1), 
Teachers' perception towards utilization of WhatsApp in supporting teaching and learning of Chemistry during COVID-19 pandemic in Rwandan selected secondary schools

E. Nsabayezu, A. Iyamuremye, J.D. Kwitonda, A. Mbonyiryivuze

18-30.

$\underline{623 X / 2019.01 .002}$

https://doi.org/10.17265/2161- 
African Journal of Educational Studies in Mathematics and Sciences Vol. 16, No. 2, 2020

Open Access article distributed under the terms of the Creative Commons Attributions License [CC BY-NC-ND 4.0] http://creativecommons.org/licenses/by-nc-nd/4.0. DOI: https://dx.doi.org/10.4314/ajesms.v16i.2.6 